\title{
Scopolamine: An Experimental Tool
}

\author{
Badruddeen ${ }^{1 *}$, Ghazanfer ${ }^{1}$, Juber Akhtar ${ }^{1}$ and Mahboobus Salam ${ }^{2}$ \\ ${ }^{1}$ Department of Pharmacology, Integral University, India \\ ${ }^{2}$ CRIUM, India
}

Submission: April 10, 2018; Published: June 22, 2018

*Corresponding author: Badruddeen, Department of Pharmacology, Faculty of Pharmacy, Integral University, Kursi Road, Lucknow-226026, India, Tel: +91-9918196188; Email: badarmiracle@gmail.com

\begin{abstract}
The aim of this review is to highlight the chemistry, pharmacological effects and experimental values of scopolamine. It is a tropane alkaloid drug with muscarinic antagonist effects, also known as Hyoscine. It is on the World Health Organization's List of Essential Medicines. Chemically it is 6,7b-epoxide of hyoscyamine, formed from hyoscyamine via 6b-hydroxyhyoscyamine. It is used to treat postoperative nausea and vomiting, gastrointestinal spasms, irritable bowel syndrome, etc. It is sometimes used as a premedication to surgery. It is experimentally used to evaluate nootropic and cholinergic drugs. Therefore it is further applied as a model for discovery and evaluation of new drugs and natural bioactive affecting cognitive function.
\end{abstract}

\section{Introduction}

Scopolamine is a tropane alkaloid drug with muscarinic antagonist effects, also known as Hyoscine. Scopolamine exerts its effects by acting as a competitive antagonist at muscarinic acetylcholine receptors; it is thus classified as an anti cholinergic (anti muscarinic) drug. Although it is generally mentioned as a nonspecific antagonist, there is secondary evidence for M1-receptor subtype specificity. It is on the World Health Organization's List of Essential Medicines, the most important medications needed in a basic health system. Scopolamine is named after the plant genus Scopolia. The name "hyoscine" is derived from the scientific name of henbane (Hyoscyamus Niger). Scopolamine has a number of uses in medicine, where it is used to treat postoperative nausea and vomiting, gastrointestinal spasms, irritable bowel syndrome, etc. It is sometimes used as a premedication (especially to reduce respiratory tract secretions) to surgery, most commonly by injection $[1,2]$.

\section{Chemistry}

Scopolamine, which is the $6,7 \mathrm{~b}$-epoxide of hyoscyamine, is formed from hyoscyamine via 6b-hydroxyhyoscyamine. Both reactions are catalysed by hyoscyamine-6b-hydroxylase $(\mathrm{H} 6 \mathrm{H})$, which is a 2-oxoglutarate-dependent deoxygenase. The enzyme is localized in the pericycle of the root and is especially active in cultured roots, but absent in aerial parts of the plant [3-5].

\section{Pharmacological Review of Scopolamine}

A. Brown et al. [2] suggested that Scopolamine may impair temporal attention through a decrease in tonic alertness and that this decrease in alertness can be temporarily compensated by a phasic alerting response to a salient stimulus.

B. Dandan et al. [6] examined harmine effects on scopolamine induced memory impairment mice and APP/ PS1 transgenic mice as one of the models for Alzheimer's disease, using Morris Water Maze test.

C. Wohleb et al. [7] proposed that scopolamine reverses the inhibitory inter neurons in the PFC causing disinhibition of pyramidal neurons and amplified extracellular glutamate that stimulates the quick antidepressant reactions to these mediators.

D. Changrun et al. [8] showed that the treatment with scopolamine significantly increased the escape latency time, decreased the number of crossings, and shortened the time spent in the target quadrant, while poly galacic acid reversed this scopolamine induced effects.

E. Andrea et al. [9] suggested that the administration of scopolamine increases the activity marker Fos in the medial prefrontal cortex, including the infralimbic (IL) and prelimbic (PrL) subregions. Scopolamine micro infusions into the IL or the PrL formed substantial antidepressant reactions in the forced swim test, and neuronal silencing of IL or PrL obstructed the antidepressant properties of systemic scopolamine. The consequences also reveal that the systemic administration of a selective muscarinic acetylcholine receptor antagonist, VU0255035, created an antidepressant reaction and stimulated mechanistic target 
of rapamycin complex 1 signaling in the $\mathrm{PFC}$, related to the actions of scopolamine.

\section{Evaluation of Nootropic Effect}

A. Badruddeen et al. [10] examined the imaginable protective result of hydro-alcoholic extract of Salvia haematodes Wall root (HESH) on cognitive purposes in scopolamine-induced amnesia in adult Sprague Dawley rats. This study was observed acquisition SDL, retention SDL and locomotor activity significantly decreased while Ach E activity significantly increased in scopolamine-treated group as compared to normal control group. The acquisition SDL, retention SDL and locomotor activity were significantly increased while; Ach E activity was significantly decreased with all the doses of HESH as compared to scopolaminetreated group.

B. Memory impairment was induced in male Wistar rats by administration of scopolamine $(1 \mathrm{mg} / \mathrm{kg}$ intra peritoneally). Rats received oral doses of ramipril $(0.225 \mathrm{mg} /$ $\mathrm{kg}$ ) and losartan $(2.25 \mathrm{mg} / \mathrm{kg})$ for a period of four weeks. Passive avoidance paradigm was used to assess learning and memory. Ramipril and losartan pre-treatment overturned the scopolamine-induced memory impairment, oxidative stress and hippocampal degeneration which were marked by the results from behavioral, biochemical and histological studies [11].

C. Saline or scopolamine ( $16 \mathrm{mg} / \mathrm{kg}$, i.p.) was administered to male Wistar rats. The other three groups were pre-treated with Nigella sativa oil (NSO) (1 ml/kg, p.o.), wheat germ oil (WGO) (170mg/kg, p.o.) and donepezil used as a reference drug (10mg/kg, p.o.) for 14 days before scopolamine injection. Cognitive and biochemical measurements were then assessed. NSO and WGO treated rat's expressively overturned scopolamine-induced shortage of spatial and non-spatial functioning memory deficiency in the $\mathrm{T}$ maze change task and object recognition test, respectively [12].

D. Naringenin (50 and $100 \mathrm{mg} / \mathrm{kg}$ ) and donepezil (2.5mg/ $\mathrm{kg}$ ) were orally administered for 7 successive days. At the end of the treatment period, dementia was prompted by a single injection of scopolamine $(20 \mathrm{mg} / \mathrm{kg}$; i.p). Scopolamine caused memory impairment that was combined by modifications in the projected neurotransmitters and acetyl cholinesterase action as well as enlarged brain oxidative stress. Pre-treatment with naringenin in both doses eased scopolamine-induced behavioural, neuro chemical and histological alterations in a manner similar to donepezil [13].

E. Morris water maze scale was engaged to test the amnesic influence of scopolamine and its reversal by $B$. monniera. Rota rod test was conducted to screen muscle coordination activity of mice. Scopolamine expressively reduced the acquisition and recovery of memory making both antero grade and retrograde amnesia [14].

\section{Evaluation of Cholinergic Activity}

i. In normal rats, Bifemelane Hydrochloride (30mg/ $\mathrm{kg}$, i.p.) slightly increased acetylcholine (ACh) content in the cerebral cortex. Scopolamine $(1 \mathrm{mg} / \mathrm{kg}$, i.p.) decreased ACh level and pre-treatment of Bifemelane Hydrochloride attenuated the decrement of ACh level in the rats [15].

ii. The properties of cholinesterase inhibitors, cholinergic agonists, dopaminergic agonists and dopaminergic antagonists on the hyperactivity resulted by the muscarinic cholinergic antagonist scopolamine were assessed in mice. Scopolamine $(0.3-10 \mathrm{mg} / \mathrm{kg})$ produced a dose-related increase in loco motor activity, with a peak effect at $3.0 \mathrm{mg} /$ $\mathrm{kg}[16]$.

iii. Atropine and scopolamine in low doses intensify basic activity, increase amphetamine stereotypy, and suppress catalepsy induced by injection of haloperidol. High doses lower body temperature, antagonize amphetamine stereotypy, and intensify the hypnotic action of chloral hydrate [17].

\section{References}

1. Petersen RC (1977) Scopolamine induced learning failures in man Psychopharmacology. Psychopharmacology (Berl) 52(3): 283289.

2. Brown SB, Slagter HA, van Noorden, MS, Giltay EJ, van der Wee NJ, et al. (2016) Effects of clonidine and scopolamine on multiple target detection in rapid serial visual presentation. Psychopharmacology 233(2): 341350 .

3. Hashimoto T, Yamada Y (1986) Hyoscyamine 6b-hydroxylase, a 2-oxoglutarate-dependent dioxygenase, in alkaloid-producing root cultures. Plant Physiol 81(2): 619-625.

4. Hashimoto T, Hayashi A, Amano Y, Kohno J, Iwanari H, et al. (1991) Hyoscyamine 6b-hydroxylase, an enzyme involved in tropane alkaloid biosynthesis, is localized at the pericycle of the root. J Biol Chem 266(7): 4648-4653.

5. Matsuda J, Okabe S, Hashimoto T, Yamada Y (1991) Molecular cloning of hyoscyamine 6b-hydroxylase, a 2-oxoglutaratedependent dioxygenase, from cultured roots of Hyoscyamus niger. J Biol Chem 266(15): 9460-9464.

6. Dandan H, Wu H, Wei Y, Liu W, Huang F, et al. (2015) Effects of harmine, an acetylcholinesterase inhibitor, on spatial learning and memory of APP/PS1 transgenic mice and scopolamine-induced memory impairment in mice. Eur J Pharmacol 768: 96-107.

7. Wohleb ES, Gerhard D, Thomas A, Duman RS (2017) Molecular and cellular mechanisms of rapid-acting antidepressants ketamine and scopolamine. Curr Neuropharmacol 15(1): 11-20.

8. Changrun G, Shen J, Meng Z, Yang X, Li F (2016) Neuroprotective effects of polygalacic acid on scopolamine-induced memory deficits in mice. Phytomedicine 23(2): 149-155.

9. Andrea N, Wohleb ES, Voleti B, Ota KT, Dutheil S, et al. (2015) Rapid antidepressant actions of scopolamine: role of medial prefrontal cortex and M1-subtype muscarinic acetylcholine receptors. Neurobiol Dis 82: 254-261. 
10. Shawwal M, Badruddeen, Khushtar M, Rahman MA (2017) Protective effect of hydro-alcoholic extract of Salvia haematodes Wall root on cognitive functions in scopolamine-induced amnesia in rats. J Tradit Complement Med 7(4): 471-475.

11. Debasree D, Veena N, Bairy KL, Mohandas RKG, Jeevan S (2013) Antiamnesic and neuroprotective effects of low dose of ramipril and losartan in scopolamine-induced amnesia model of dementia Res J Pharm Biol Chem Sci 4(1): 1174-1182.

12. Salma AE, Siham ME, Aiman SE, Osama AE, Sanaa AK (2012) Effect of Nigella sativa and wheat germ oils on scopolamine induced memory impairment in rats. Bulletin Faculty Pharm, Cairo University 50(2): 8188.

13. Hala FZ, May AA, Amina SA (2014) Naringenin protects against scopolamine induced dementia in rats. Bulletin Faculty Pharm, Cairo University 52(1): 15-25.
14. Saraf MK, Prabhakar S, Khanduja KL, Anand A (2011) Bacopa monniera attenuates scopolamine-induced impairment of spatial memory in mice. Evid-Based Complement Alternat Med 2011: 236186.

15. Saitoh T, Kinoshita T, Shibata S (1976) Flavonols of licorice root. Chem Pharma Bulletin 24(6): 1242-1245.

16. Shannon HE, Peters SC (1990) A comparison of the effects of cholinergic and dopaminergic agents on scopolamine-induced hyperactivity in mice. J Pharmacol and Experiment Therapeut 255(2): 549-553.

17. Zebrowska LI, Kleinrok Z, Poddubiuk Z (1975) Central action of drugs acting on the cholinergic muscarinic receptor. III. Influence of atropine and scopolamine injected intraventricularly on behavior and levels of biogenic amines in the rat brain. Arch Immunol Ther Exp 23(4): 485495.

\section{Your next submission with Juniper Publishers will reach you the below assets}

- Quality Editorial service

- Swift Peer Review

- Reprints availability

- E-prints Service

- Manuscript Podcast for convenient understanding

- Global attainment for your research

- Manuscript accessibility in different formats

( Pdf, E-pub, Full Text, Audio)

- Unceasing customer service

Track the below URL for one-step submission https://juniperpublishers.com/online-submission.php 